\title{
Chapter 12 \\ Standard-Setting in Water Use \\ and Sustainable Development: \\ A Comparative Critical Analysis of Grey \\ Water Recycling in the Tourism Sector
}

\author{
André Coelho, Alexandre Domingues, Maria Cândida A. de M. Mousinho, \\ and Cassia Saretta
}

\section{Introduction}

Tourism is a key sector for studies related to sustainability and the use of natural resources towards truly inclusive development. The sector is responsible for nearly $10 \%$ of the world's GDP and for the generation of 280 million jobs. In 2015, approximately 1 billion tourists performed domestic or international trips, circulating trillions of dollars in the world economy (World Travel \& Tourism Council, 2016). The number of international tourist arrivals worldwide is expected to increase by an average of $3.3 \%$ a year over the period 2010 to 2030 (UNWTO, 2016). Cited by the United Nations (UN) as the strongest sector for job creation (United Nations General Asembly, 2014), it is, however, also responsible for an aggressive use of resources such as water, food, wood and fossil fuels. Despite the fact that it is an industry related to leisure and cultural awareness, the sector has a deep impact on the use of natural resources and natural services.

In contemporary society, water is, in its most simple form of understanding, synonymous with life. It is no wonder that the astronomical sciences search for this natural resource in other spheres of the universe as evidence of the possibility of life. More concretely, the fact is that human beings have always needed this natural

\footnotetext{
A. Coelho $(\varangle)$

Fundação Getulio Vargas (FGV), Rio de Janeiro, Brazil

e-mail: andre.coelho@fgv.br
}

A. Domingues

Ministry of Planning, Budget and Management, Brasília, Brazil

M. C. A. de M. Mousinho

Federal Institute of Education, Science and Technology (IFBA), Salvador, Brazil

C. Saretta

Ministry of Environment/Brazilian Forest Service (BFS), Brasília, Brazil 
resource as a source of livelihood and it is an unassailable reality that they will continue to do so. The scientific and technological advances in the areas of food, health, transport, for example, would not have been possible without the systematic use of water, which shows that this source is not only a fundamental need for human existence, but crucial for the realization of all other needs.

The implementation of up-to-date sustainability standards or practices aligned with a multi-stakeholder regulatory framework for water use may complement the international collaboration on new solutions at local, national and regional levels. In order to establish a pilot study, this chapter aims to understand to what extent standards and regulations apply to the sustainable use of water in the hotel industry. The study highlights the multi-stakeholder nature of sustainability standards, using the tourism sector in an exploratory and comparative analysis of the tourist areas of two major cities. Rio de Janeiro, in Brazil, was used as an example of an internationally appealing Latin American city without any formal standards for water use. Berlin, in Germany, was used as a seemingly contrasting example for the implementation of sustainability standards.

\section{Tourism and Sustainable Development}

Several authors have studied the tourism industry from the perspective of sustainability, focusing on aspects relating to its carbon footprint (Sun, 2014), energy, culture, water and environmental impacts as a whole (Aall, 2011; Collins, Jones, \& Munday, 2009; Law \& Cheung, 2007; Li, Wichmann, \& Otterpohl, 2009; Radwan, Jones, \& Minoli, 2012). They have all gained prominent attention in recent years as the notion of the environmental externality of tourism growth has found focus.

The conceptual framework of sustainability seems to be in accordance with the growth of the leisure industry, as the main tourism products (segments) in the world are directly linked to natural resources (Beach \& Sun, Ecotourism and Cultural Tourism). Sustainability is a concept that focuses on the fate of the next generations; it is based on the challenge of maintaining the lifestyle of the present in the future (Georgescu-Roegen, 1971). The effects of the increase of tourists circulating in the world are thus not to be measured in terms of their current status but are to be viewed in the context of their long-lasting impact.

The activities of tourists at destinations are additional to those of local residents and regular transit visitors, and their presence adds to the overall environmental impact at the location. Several studies prove that the use of natural resources by someone who is not a local resident is at least two times higher than the optimal use by a local user (Aall, 2011; Gössling et al., 2012; International Network on Regional Economics, Mobility and Tourism \& World Tourism Organization, 2012; Law \& Cheung, 2007; Martinez-Alier, 2015). According to Li, Yang, Liu, and Zheng (2014), tourist flow has a seasonal diversity, with strong effects in the peak season (usually the summer half of the year in most destinations) and weak effects in the off-season (usually the winter half of the year in most destinations) (Gatt \& Schranz, 2015). Local 
destinations with high tourist flow are certain to experience environmental effects, comparable to cities. Similar to urban island effects in cities, tourist destinations are expected to have destination island effects, in which one or more environmental indexes are significantly higher than those of the surrounding non-tourism areas.

The hospitality business - especially hotels - has been studied as a driver of sustainability standards in tourism as the main employer (workforce) in the sector and as one of the biggest sectors in terms of financial movements for investments (Gatt \& Schranz, 2015; Li, Yang, Liu, \& Zheng, 2014; Rahman, Dayang-Affizzah, $\&$ Edman, 2012). Hotels are involved in several aspects of sustainability, from white papers and corporate commitments to cleaner operation that is recognized by the client, who, sometimes, endorses that by expressing loyalty to the brand. From the used towels that should be hung and reused to solar panels that capture energy to warm up pools and spa areas; from water reuse procedures to roof panels that capture rainwater for gardening use, big chains and small hospitality businesses have been studied in several contexts, but the literature does not show a major concern for expanding the sustainbility impacts of local tourism as a worldwide concern.

Focusing on tourism accommodation as the locus of tourism, water consumption and conventional water indicators are reviewed and discussed, and knowledge gaps identified. From the tourism sector to regular home use, industrial consumption or agricultural irrigation, the use of water is key to pursuing a quality of life. Its use has proved contentious both in economic terms and in socio-cultural and environmental terms. The relationship between humankind and nature sometimes lacks complementarity - as when usage that is necessary for self-sufficiency turns into usage in a hegemonic, exploitative mode.

\section{The Use of Water and Sustainability}

Not only is water the most important natural resource in all economic cycles, it is central to the very survival of human beings on the planet. How to properly use this source is a crucial challenge in contemporary society-especially considering a scenario in which the demand for water is expected to increase by $55 \%$ by 2050 . In addition to this, we must consider the lack of accessibility to this source-approximately 800 million people do not have access to quality drinking water in the world. Environmental issues are significant as well-projections indicate change in temporal and spatial distribution of water resources, potentially leading to hydrological disasters (WWAP, 2015).

Water management standards may become the norm in the future (Styles, Schoenberger, \& Galvez-Martos, 2015). A general review of the use of water is an urgent issue when it comes to human needs and consumption. Even considering that most of the water available in the world is used in agricultural and industrial operations, regular personal use also needs to be addressed (Charara, Cashman, Bonnell, \& Gehr, 2011; Gössling, 2015; Li, Wichmann, \& Otterpohl, 2009; Millimet \& Roy, 2015; Styles et al., 2015). 
Several normative standards apply to a variety of water management and recycling techniques. The International Organization for Standardization (ISO) has more than 200 norms on water recycling systems, from portability criteria to equipment installation processes. Most countries also have local norms that apply and that follow the same path. Table 1 shows examples of ISO standards regarding water reuse.

Thus, the management of water resources does not depend exclusively on public entities, but also on a range of private actors (Jiménez-Cisneros, 2014). The entry of the business sector, taking advantage of an emerging green market (MontibellerFilho, 2004), was characteristic of environmentalism in the 1990s and a positive factor for sustainable development. It should be noted that, already in the mid-1990s, the concept of sustainable development had been translated into a model to guide business practice that would be economically viable and at the same time socially and environmentally sustainable (Vizeu, Meneghetti, \& Seifert, 2012). Similarly, the ever-growing number of voluntary sustainability standards (VSS) - many of them

Table 1 Examples of ISO standards regarding water reuse

\begin{tabular}{|c|c|c|}
\hline Source (Techn. Committee) & Normative standard examples & Further details \\
\hline $\begin{array}{l}\text { ISO/TC } 147 \\
\text { Participating countries: } 42 \\
\text { Creation date: } 1971\end{array}$ & $\begin{array}{l}\text { Standardisation in the field of } \\
\text { water quality, including } \\
\text { definition of terms, sampling of } \\
\text { water, measurement and } \\
\text { reporting of water } \\
\text { characteristics }\end{array}$ & $\begin{array}{l}\text { Total number of published ISO } \\
\text { standards related to TC } 147 \text { and } \\
\text { its SCs (number includes } \\
\text { updates): } 288\end{array}$ \\
\hline $\begin{array}{l}\text { ISO/TC } 224 \\
\text { Participating countries: } 35 \\
\text { Creation date: } 2001\end{array}$ & $\begin{array}{l}\text { Standardisation of a framework } \\
\text { for the definition and } \\
\text { measurement of service } \\
\text { activities relating to drinking } \\
\text { water supply systems and } \\
\text { wastewater systems }\end{array}$ & $\begin{array}{l}\text { Four published ISO standards } \\
\text { under the direct responsibility of } \\
\text { ISO/TC } 224 \\
\text { (1) ISO } \\
24510: 2007 \text { - Guidelines } \\
\text { for the assessment and for } \\
\text { the improvement of the } \\
\text { service to users } \\
\text { (2) ISO } \\
24511: 2007 \text {-Guidelines } \\
\text { for the management of } \\
\text { wastewater utilities and for } \\
\text { the assessment of } \\
\text { wastewater services } \\
\text { (3) ISO } \\
24512: 2007 \text {-Guidelines } \\
\text { for the management of } \\
\text { drinking water utilities and } \\
\text { for the assessment of } \\
\text { drinking water services } \\
\text { (4) ISO } 24518: 2015-\text { Crisis } \\
\text { management of water } \\
\text { utilities }\end{array}$ \\
\hline
\end{tabular}


Table 1 (continued)

\begin{tabular}{l|l|l}
\hline Source (Techn. Committee) & Normative standard examples & Further details \\
\hline $\begin{array}{l}\text { ISO/TC 282 Water reuse } \\
\text { Preation dating countries: } 21\end{array}$ & $\begin{array}{l}\text { ISO 16075:2015 - } \\
\text { Guidelines for treated } \\
\text { wastewater use for irrigation } \\
\text { projects }\end{array}$ & $\begin{array}{l}\text { Scope: Standardisation of water } \\
\text { reuse of any kind and for any } \\
\text { purpose. It covers centralized } \\
\text { and decentralised or onsite water } \\
\text { reuses, direct and indirect ones } \\
\text { as well as intentional and } \\
\text { unintentional ones. It includes } \\
\text { technical, economic, } \\
\text { environmental and societal } \\
\text { aspects of water reuse. Water } \\
\text { reuse comprises a sequence of } \\
\text { the stages and operations } \\
\text { involved in uptake, conveyance, } \\
\text { processing, storage, distribution, } \\
\text { consumption, drainage and other } \\
\text { handling of wastewater, } \\
\text { including the water reuse in } \\
\text { repeated, cascaded and recycled } \\
\text { ways. The scope of ISO/TC 253 } \\
\text { (treated wastewater reuse for } \\
\text { irrigation) is merged into the } \\
\text { proposed new committee. }\end{array}$ \\
\hline
\end{tabular}

Source Authors: compiled from https://www.iso .org

developed by coalitions of non-state actors-have provided market-based mechanisms for sustainability in production and consumption, e.g. for sustainable resource use.

Among the several procedures and practices for the sustainable use of water (which may or may not be required by a specific sustainability standard), the use of grey water is a reference to saving fresh, clean or treated water from regular human use. In the context of this chapter, we will focus on water use by tourists and corresponding opportunities for grey water recycling.

\section{Grey Water as a Driver for the Safer Use of Natural Resources}

Grey water is a type of wastewater generated in hotels, households or office buildings from sinks, showers, baths, washing machines or dishwashers. It is considered as containing fewer pathogens than domestic wastewater and is generally safer to handle and easier to treat and reuse onsite for toilet flushing, landscape or crop irrigation and other non-potable uses. The application of grey water reuse in major buildings such as hotels provides substantial benefits for both the water supply subsystem by reducing the demand for fresh clean water as well as the wastewater subsystems by reducing the amount of wastewater required to be conveyed and treated. It is economically viable in most aspects for major operations and simple to implement (Al-Jayyousi, 2003; Gatt \& Schranz, 2015; Styles et al., 2015). Grey water, by definition, is different from discharge of toilets and contaminated wastewater, which is designated as black 
water to indicate that it contains human waste. The implementation of the system is technically feasible; it is basically a matter of civil engineering arrangements to reallocate pipes that will be connected to an alternative discharge system.

\section{Methodology}

This chapter evaluates two hotel samples in two major tourist cities in the world and checks the use of grey water recycling systems. This is not a statistical study, but an exploratory analysis with both primary and secondary data. Therefore, the process of separation of the sample follows two basic criteria: (1) geographical criteria, which means that the hotel should be in a predominantly tourist area; (2) a qualification criterion, which means that within the selected areas, only the best-evaluated hotels ${ }^{1}$ (three to five stars) were selected to respond. After the methodological criteria application, not more than thirty hotels were selected in each city and contacted over telephone in the second half of 2015 to respond to three questions: (1) existence of grey water system; (2) total number of rooms; and (3) number of rooms connected to the system.

The chosen cities were Rio de Janeiro in Brazil and Berlin in Germany. For the Brazilian sample, 27 hotels responded to the research, all located in the Copacabana tourist region. In the German sample, 18 hotels responded to the research, mostly located in Berlin Mitte. All hotels contacted were members of major alliances or had a capacity for meeting international sustainability standards.

The data references were based on the literature for grey water use, which estimates that freshwater consumption for high-end hotels with more than 100 rooms is, for example, 126 litres per day (1/day), considering exclusive individual use (shower/bath/sink) plus the use of 12 1/day for cleaning (Styles et al., 2015). This adds up to 138 1/day, without the consideration of toilet use (aim of this article). Other studies based on Nolde (2000) complement the findings of Gössling (2015) and suggest 95 and 81 1/day as references for individual use (shower/bath/sink). Experiments conducted in a summer hotel on the Spanish island of Mallorca suggest 110 1/day (March, Gual, \& Orozco, 2004), a number that was considered for our calculations of annual water use in hotels of the Copacabana region (Sample 1). For hotels in Berlin (Sample 2), a different value (81 1/day) was used to reflect different toilet water discharge equipment, cultural factors and weather conditions influencing water use.

The parameters for toilet discharge of water (not suited for recycling) were also derived from March et al. (2004) for Sample 1 (Copacabana) and amounted to 361/day for individual use; Styles et al. (2015) (381/day), Nolde (2000) (571/day) and Gössling (2015) (21 1/day) do not differ much from this number. For the above-mentioned

\footnotetext{
${ }^{1}$ Evaluations based on Trip Advisor's standards. The hotels were investigated in specific tourist areas.
} 
reasons (technical, cultural and weather-related factors), the lowest number (21 1/day) from this row was again used to calculate annual values for Sample 2 (Berlin).

Given their exploratory and approximate character, the quantitative results in Table 3 (Sect. 5) are not meant to statistically evaluate and rank the two tourist regions under review, but rather to present a broad spectrum of different water use patterns and saving potentials based on two simplified examples.

In addition, eight hotel maintenance managers were willing to complement our quantitative estimates with more detailed interviews. They were interviewed in order to check for two conditions: (1) whether the implementation was driven by an external requirement or by a strategic decision of the hotel managers and (2) whether there were sustainability standards or procedures on grey water to be followed.

\section{Results and Analysis}

In the hotel business, several procedures are currently applied to mitigate the environmental impacts of major hospitality operations in tourist destinations, but, in most cases, they are driven by internal regulations, market strategies or certification. According to the literature referenced in this chapter, the reuse of grey water is currently one of the easiest procedures used by hotels to reduce the use of freshwater, but its use is restricted to some hotels only and the reasons for this limited application are still not clear.

For the qualitative questions, seven out of eight managers interviewed highlighted that there was no specific sustainability standard mandating them to use grey water systems. In fact, each company implemented the equipment based on its own evaluation. One manager mentioned public incentives for hotels following specific sustainable criteria related to electric energy and water use. Table 2 shows the requirements and standards implemented by hotels.

The qualitative results indicate that hotels using recycling systems were driven by interests related to their own evaluations and expectations-from economic

Table 2 Qualitative interviews with hotel maintenance managers

\begin{tabular}{l|l|l}
\hline Sample & $\begin{array}{l}\text { Motivation for the implementation of } \\
\text { grey water system }\end{array}$ & Sustainability standards in place \\
\hline Copacabana group & $\begin{array}{l}\text { All managers said that it was an } \\
\text { internal strategic decision without any } \\
\text { external direction }\end{array}$ & $\begin{array}{l}\text { No sustainability standards, but } \\
\text { technical standards for water } \\
\text { potability and system installation }\end{array}$ \\
\hline Berlin Mitte group & $\begin{array}{l}\text { Three managers mentioned that it was } \\
\text { an internal decision and one } \\
\text { mentioned a possible public fund for } \\
\text { sustainability practices, including } \\
\text { other activities related to energy }\end{array}$ & $\begin{array}{l}\text { No sustainability standards, but } \\
\text { technical standards for water } \\
\text { potability and system installation }\end{array}$ \\
\hline
\end{tabular}

Source Authors 
savings to recognition through clients and contributions to international brands' white papers. This suggests that standards towards sustainable tourism and the common good, unlike standards for technical operations, are not yet common, at least in the sample sector and regions, even though such initiatives in principle exist (e.g. Rainforest Alliance Verification Standard for Tourism Services, Travelife Award, Global Sustainable Tourism Criteria/GSTC and a range of regional/national schemes). Additionally, the companies did not follow any regulatory procedure that could work as an incentive to the implementation of a recycling water system.

The quantitative results are displayed in Table 3. Out of 27 hotels analyzed in Rio de Janeiro, only four had a grey water management system in operation, while out of 18 hotels consulted in Berlin, seven of them had one. Since water use and saving rate per unit were assumed to be higher for the Brazilian sample than for the German one, the total amount of savings was also higher (Table 3) although less hotels had a recycling system in place. In turn, as the proportion of hotels using a recycling system was much lower in the overall Brazilian sample compared to the German one, the amount saved in Rio de Janeiro was proportionally lower than in Berlin. However, even considering that the results for Berlin were better than for the

Table 3 Major quantitative results for water savings

\begin{tabular}{|c|c|c|c|c|}
\hline & $\begin{array}{l}\text { Total use/savings } \\
\text { of the sample (1) }\end{array}$ & $\begin{array}{l}\text { Total use/savings of } \\
\text { the samples }\left(M^{3}\right)\end{array}$ & Olympic pools ${ }^{\mathrm{g}}$ & $\%$ of total use \\
\hline 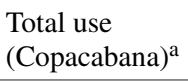 & $413,043,968.88$ & $413,043.97$ & 165.2 & - \\
\hline $\begin{array}{l}\text { Total use } \\
{\text { (Berlin })^{\mathrm{b}}}\end{array}$ & $248,847,710.02$ & $248,847.71$ & 99.5 & - \\
\hline $\begin{array}{l}\text { Total savings } \\
\text { (Copacabana) }^{\mathrm{c}}\end{array}$ & $28,249,239.24$ & $28,249.24$ & 11.3 & 6.84 \\
\hline $\begin{array}{l}\text { Total savings } \\
(\text { Berlin })^{\mathrm{d}}\end{array}$ & $20,077,118.46$ & $20,077.12$ & 8.0 & 8.07 \\
\hline $\begin{array}{l}\text { Total possible } \\
\text { savings } \\
\text { (Copacabana) }^{\mathrm{e}}\end{array}$ & $101,846,458.08$ & $101,846.46$ & 40.7 & 24.66 \\
\hline $\begin{array}{l}\text { Total possible } \\
\text { savings } \\
(\text { Berlin })^{\mathrm{f}}\end{array}$ & $57,426,394.62$ & $57,426.39$ & 23.0 & 23.08 \\
\hline
\end{tabular}

\section{Source Authors}

${ }^{\text {a}}$ Estimated total (fresh) water use per year of the Brazilian sample (27 hotels, all rooms)

${ }^{\mathrm{b}}$ Estimated total (fresh) water use per year of the German sample (18 hotels, all rooms)

${ }^{\mathrm{c} E s t i m a t e d ~ w a t e r ~ s a v i n g s ~ i n ~ o n e ~ y e a r ~ o f ~ o p e r a t i o n ~ o f ~ g r e y ~ w a t e r ~ r e c y c l i n g ~ f o r ~ t h e ~ B r a z i l i a n ~ s a m p l e ~}$ (4 hotels out of 27 , only those rooms connected to the system were considered)

${ }^{\mathrm{d}}$ Estimated water savings in one year of operation of grey water recycling for the German sample ( 7 hotels out of 18 , only those rooms connected to the system were considered)

e, $\mathrm{f}$ Total possible savings if $100 \%$ of the sample had the system

g Average Olympic pool with 2.5 million litres 
Brazilian sample, the majority of hotels consulted did not have the system in either country.

Among our findings, there is a clear conclusion that the use of recycling systems for water is relevant in terms of the volume saved in the tourism industry. Just considering water savings in the studied sample, the results show that $6.86 \%$ and $8.07 \%$, respectively, of the total water used in one year across the two samples were saved. Translating these results into commonly understood terms, in the Brazilian sample there was a total saving equivalent to 11 Olympic water pools in one year of operation among the rooms with the system installed. In Germany, 8 Olympic water pools could be saved within the sample analyzed. A greater result could be expected if the whole industry in one city would be using this recycling system.

Exploring our data and case studies from literature, on average, hotels using recycling systems may save between 20 and $25 \%$ of all the water used in their rooms. Since neither standards nor regulations play a major role across these samples as a driver for sustainability yet, they needed to be rebalanced, especially towards more regulatory procedures. At present, hotels are simply taking their own initiatives.

\section{Towards a Regulatory Framework}

The primary research has highlighted a trend. Across the globe, there are significant differences in water consumption with respect to resource endowment, pollution, technical composition, natural cycle, recycling, etc. In addition to estimating and comparing the use of freshwater for human consumption and commercial use we came across a simple conclusion: there is a need to eliminate endogeneity and transform the process of saving this natural resource into a regulatory framework, where private and public sectors could benefit from reduced consumption and from recycling.

The process of "greening" the tourism industry is not an easy task. However, for the cases studied, environmental regulation can exert a significant effect on commercial productivity. It is a matter of implementing voluntary standards and mandatory regulations before relevant economic variables reach the critical point affected by the scarcity of water. Here, we have made an empirical estimation of the threshold characteristics of environmental regulation for tourism, and simple suggestions can already be put in place.

In the voluntary field, the adoption of sustainable practices is already happening in the hotel industry, but, as we could map, even for high-end brands the adoption of technical procedures to save water is not related to political encouragement or pressure but to an economic motivation. This is not a bad thing, but it could be much better executed if there would be an official yet voluntary framework to guide market actions. The Sustainable Development Goals (SDGs) could be a relevant starting point to link voluntary practices of the tourism industry, such as grey water recycling, to broader questions of sustainability and the management of natural resources in the global arena. Voluntary standards for sustainable tourism, as mentioned in Sect. 5, can constitute an important instrument to substantiate and implement the SDGs in this sector. 
Within the SDGs framework, there are several topics that relate to the discussion raised in this chapter and the proper adoption of these concepts could lead to betterorganized activities for saving freshwater. Table 4 highlights the potential of selected SDGs to guide transformation in three categories related to this chapter: sustainability cooperation, water use and tourism.

In addition to voluntary standards adoption based on SDGs, mandatory regulation may be required. Considering that regulatory actions for protecting the environment vary significantly from industry to industry (including tourism), while different industries may respond differently to the same regulation, it is important to introduce more effective regulatory incentives towards the sustainable use of water. Indeed, environmental regulation has a significant positive correlation with increased environmental productivity

Table 4 Themes of this chapter as reflected in selected SDGs

\begin{tabular}{|c|c|c|}
\hline Sustainability cooperation & Water use & Tourism \\
\hline $\begin{array}{l}17.1 \\
\text { Strengthen domestic resource } \\
\text { mobilization, including } \\
\text { through international support } \\
\text { to developing countries, to } \\
\text { improve domestic capacity for } \\
\text { tax and other revenue } \\
\text { collection } \\
17.14 \\
\text { Enhance policy coherence for } \\
\text { sustainable development } \\
17.17 \\
\text { Encourage and promote } \\
\text { effective public, public-private } \\
\text { and civil society partnerships, } \\
\text { building on the experience and } \\
\text { resourcing strategies of } \\
\text { partnerships }\end{array}$ & $\begin{array}{l}6.4 \\
\text { By 2030, substantially increase } \\
\text { water use efficiency across all } \\
\text { sectors and ensure sustainable } \\
\text { withdrawals and supply of } \\
\text { freshwater to address water } \\
\text { scarcity and substantially } \\
\text { reduce the number of people } \\
\text { suffering from water scarcity } \\
6.5 \\
\text { By } 2030 \text {, implement integrated } \\
\text { water resources management } \\
\text { at all levels, including through } \\
\text { transboundary cooperation as } \\
\text { appropriate } \\
6 . \text { a } \\
\text { By } 2030, \text { expand international } \\
\text { cooperation and } \\
\text { capacity-building support to } \\
\text { developing countries in water- } \\
\text { and sanitation-related activities } \\
\text { and programmes, including } \\
\text { water harvesting, desalination, } \\
\text { water efficiency, wastewater } \\
\text { treatment, recycling and reuse } \\
\text { technologies } \\
\text { 6.b } \\
\text { Support and strengthen the } \\
\text { participation of local } \\
\text { communities in improving } \\
\text { water and sanitation } \\
\text { management }\end{array}$ & $\begin{array}{l}8.9 \\
\text { By 2030, devise and } \\
\text { implement policies to promote } \\
\text { sustainable tourism that } \\
\text { creates jobs and promotes } \\
\text { local culture and products } \\
12.6 \\
\text { Encourage companies, } \\
\text { especially large and } \\
\text { transnational companies, to } \\
\text { adopt sustainable practices } \\
\text { and to integrate sustainability } \\
\text { information into their } \\
\text { reporting cycle } \\
12.8 \\
\text { By 2030, ensure that people } \\
\text { everywhere have the relevant } \\
\text { information and awareness for } \\
\text { sustainable development and } \\
\text { lifestyles in harmony with } \\
\text { nature } \\
12 . b \\
\text { Develop and implement tools } \\
\text { to monitor sustainable } \\
\text { development impacts for } \\
\text { sustainable tourism that } \\
\text { creates jobs and promotes } \\
\text { local culture and products }\end{array}$ \\
\hline
\end{tabular}

Source Authors' compilation based on the 2030 Agenda for Sustainable Development 
A regulatory framework towards the better use of water in tourism and other commercial activities could be the result of an evolution. Continuous changes must be achieved because as the recycling water concept matures, policymakers have to face new challenges. The introduction of mandatory regulation for water use in tourism should be based on at least three considerations:

1. Technological and cost evolution: rigid and at the same time flexible schemes may be required ranging from tax benefits to special financing lines for infrastructure;

2. Socio-economic justice: as water is a natural resource that belongs to everyone, even considering that tourists pay their share for its use, it is still a use that causes social, economic and environmental impacts and this must be registered;

3. New concepts for renewable water sharing: as shares of renewable water use increase, policymakers, managers and the public in general need to address new challenges and priorities, such as sharing the recycled water in neighbourhoods for multipurpose use.

Policymakers play a key role in shaping policy regulatory actions and public support schemes such as financing lines. According to González and Lacal-Arántegui (2016), the proper design of a scheme and of the administrative procedures for accessing it is essential in order to reduce uncertainty. This would not only avoid discouraging investors, but also reduce the overall cost of the support scheme. Higher risk needs to be compensated with higher remuneration levels in order to keep the support scheme attractive for investors. The best sustainability practice is one with clear economic and social benefits and substantial environmental protection, and this seems to be the case for grey water recycling.

\section{Policy Recommendations}

Regarding the use of water by tourists, it is clear that tourists use more water than regular citizens in similar activities. Recycling systems are the future of water use in major hotels, but the existence of standards does not have any strong relationship to present activities towards sustainability in this matter. In this context, reflection on the sustainable use of water becomes essential. The choice is not between socioeconomic development and the environment, but between development models, sensitive or not to the environment. Sustainable development should be underpinned by the ethical idea of avoiding harm to what is necessary to preserve, regardless of the existence of formal restrictions. In the end, it is the behaviour of any social actor that defines outcomes (Sachs, 2015).

To a relevant extent, sustainable development requires good governance: public and corporate. As such, combining public and private initiatives regarding standards and regulations might be a way of moving forward more effectively, given the issue's global scale and the need for transparency as well as participation. Sustainable behaviour begins with voluntary actions as an ethical idea although it is likely that positive and negative incentives are needed. 
Free market believers would argue that, in the absence of rules clearly declaring that certain behaviour is not allowed, corporate enterprises would not have a moral obligation to their shareholders to pursue any objective other than maximizing profits, even given that some measures are possible only due to circumstantial legal loopholes (Sachs, 2015). In this light, it is relevant to create social understanding on how society could together reshape thinking that might help tackle ongoing problems and, consequently, develop a more successful path towards sustainability.

Significantly, regulation is a concept that must be addressed in addition to the relevant (voluntary) standardization of sustainable action. The idea that regulation should go hand in hand with standards is much more promising than merely negative incentives, i.e. much more can be done than just restricting behaviour and preventing undesirable activities. It is feasible to develop policies that would enable, or at least facilitate, the flourishing of values through a positive approach. In sum, not only is it important to develop measures to restrict unsustainable behaviour-penalties, sanctions etc.- but it is also necessary to create opportunities for the development of public goods such as funds, technical assistance and capacity building (Baldwing, Cave, \& Lodge, 2012). By taking full advantage of positive and negative regulatory approaches, it is possible to handle policy issues with a variety of tools and standards, and consequently achieve better outcomes.

As a contribution to future debates, it is important to highlight some key aspects. First, this chapter aimed to make a pilot study of a sensitive issue that has a massive impact on people's lives: water use. It would be relevant if further research could explore this idea and evaluate what is happening in the other strategic tourist cities of the world. Those studies would allow the creation of more objective evidence-based policies. Moreover, it is clear that the UN World Tourism Organization (UNWTO) should improve its framework in relation to water use standards. The lack of transparency and guidance, on the one hand, makes it difficult for the industry to develop proper voluntary sustainability investment decisions, and, on the other hand, for the consumers to choose wisely between different products. Both sides are acting in the absence of proper information and are not necessarily making the best possible choices. Last and more importantly, it is relevant to take advantage of the SDGs to develop a smart international policy framework on the issue. Taking the SDGs as a reference point seems to be the most effective way of designing balanced (voluntary and mandatory; positive and negative; local and international) governance models to enable not only improvements in touristic practices all over the world but also to tackle instances of improper green washing behaviour.

Finally, as an incentive for further research on the topic, three policy recommendations may be collected from our exploratory research:

1. To expand the case studies on water use, either technical, behavioural, economic or political, in order to achieve substantial knowledge that could underpin evidence-based regulatory policies.

2. To advocate leadership of the UNWTO and other UN agencies in providing guidance towards use of standards and regulations on water use. 
3. To use the SDGs framework as a reference for the development of specific voluntary standards and mandatory regulations that could guide stakeholders to achieve the best levels of sustainability, meaning, not only protecting natural resources, but also achieving economic and social development.

\section{References}

Aall, C. (2011). Energy use and leisure consumption in Norway: An analysis and reduction strategy. Journal of Sustainable Tourism, 19(6), 729-745. https://doi.org/10.1080/09669582.2010.536241.

Al-Jayyousi, O. R. (2003). Greywater reuse: Towards sustainable water management. Desalination, 156(1-3), 181-192. https://doi.org/10.1016/S0011-9164(03)00340-0.

Baldwing, R., Cave, M., \& Lodge, M. (2012). Undestanding regulation (2nd ed.). Oxford: Oxford University Press.

Charara, N., Cashman, A., Bonnell, R., \& Gehr, R. (2011). Water use efficiency in the hotel sector of Barbados. Journal of Sustainable Tourism, 19(2), 231-245. https://doi.org/10.1080/09669582. 2010.502577.

Collins, A., Jones, C., \& Munday, M. (2009). Assessing the environmental impacts of mega sporting events: Two options? Tourism Management, 30(6), 828-837. https://doi.org/10.1016/j.tourman. 2008.12.006.

Gatt, K., \& Schranz, C. (2015). Retrofitting a 3 star hotel as a basis for piloting water minimisation interventions in the hospitality sector. International Journal of Hospitality Management, 50, 115-121. https://doi.org/10.1016/j.ijhm.2015.06.008.

Georgescu-Roegen, N. (1971). The entropy law and the economic process. The Economic Journal, 83 (1st ed. Boston: Harvard University Press). http://doi.org/10.2307/2231206.

González, J. S., \& Lacal-Arántegui, R. (2016). A review of regulatory framework for wind energy in European Union countries: Current state and expected developments. Renewable and Sustainable Energy Reviews, 56, 588-602. https://doi.org/10.1016/j.rser.2015.11.091.

Gössling, S. (2015). New performance indicators for water management in tourism. Tourism Management, 46, 233-244. https://doi.org/10.1016/j.tourman.2014.06.018.

Gössling, S., Peeters, P., Hall, C. M., Ceron, J.-P., Dubois, G., Lehmann, L. V., et al. (2012). Tourism and water use: Supply, demand, and security. An international review. Tourism Management, 33(1), 1-15. https://doi.org/10.1016/j.tourman.2011.03.015.

International Network on Regional Economics, Mobility and Tourism, \& World Tourism Organization (2012). A closer look at tourism: Sub-national measurement and analysis-Towards a set of UNWTO guidelines. Madrid: UNWTO Press.

Jiménez-Cisneros, B. (2014). Comprehensive water quality and purification. Comprehensive water quality and purification. Amsterdam: Elsevier. https://doi.org/10.1016/B978-0-12-382182-9.000 54-2.

Law, R., \& Cheung, C. (2007). Air quality in Hong Kong: A study of the perception of international visitors. Journal of Sustainable Tourism, 15(4), 390-401. https://doi.org/10.2167/jost637.0.

Li, F., Wichmann, K., \& Otterpohl, R. (2009). Review of the technological approaches for grey water treatment and reuses. Science of the Total Environment, 407(11), 3439-3449. https://doi. org/10.1016/j.scitotenv.2009.02.004.

Li, G., Yang, X., Liu, Q., \& Zheng, F. (2014). Destination island effects: A theoretical framework for the environmental impact assessment of human tourism activities. Tourism Management Perspectives, 10, 11-18. https://doi.org/10.1016/j.tmp.2013.12.001.

March, J. G., Gual, M., \& Orozco, F. (2004). Experiences on greywater re-use for toilet flushing in a hotel (Mallorca, Island, Spain). Desalination, 164(3), 241-247. https://doi.org/10.1016/S00119164(04)00192-4. 
Martinez-Alier, J. (2015). International encyclopedia of the social \& behavioral sciences. Amsterdam: Elsevier. http://doi.org/10.1016/B978-0-08-097086-8.91008-0

Millimet, D. L., \& Roy, J. (2015). Multilateral environmental agreements and the WTO. Economics Letters, 134, 20-23. https://doi.org/10.1016/j.econlet.2015.05.035.

Montibeller-Filho, G. (2004). O Mito do Desenvolvimento Sustentável: Meio ambiente e custos sociais no moderno sistema produtor de mercadoria. Florianopolis: UFSC.

Nolde, E. (2000). Greywater reuse systems for toilet flushing in multi-storey buildings \pm over ten years experience in Berlin. Journal of Urban Water, 2(3), 275-284. https://doi.org/10.1016/ S1462-0758(00)00023-6.

Radwan, H. R. I., Jones, E., \& Minoli, D. (2012). Solid waste management in small hotels: A comparison of green and non-green small hotels in Wales. Journal of Sustainable Tourism, 20(4), 533-550. https://doi.org/10.1080/09669582.2011.621539.

Rahman, D. H. A. A., Dayang-Affizzah, A., \& Edman, S. (2012). Tourism and hotels in Sarawak: Economic performance. Procedia-Social and Behavioral Sciences, 65, 1020-1026. https://doi. org/10.1016/j.sbspro.2012.11.236.

Sachs, J. (2015). The age of sustainable development. New York: Columbia University Press.

Styles, D., Schoenberger, H., \& Galvez-Martos, J. L. (2015). Water management in the European hospitality sector: Best practice, performance benchmarks and improvement potential. Tourism Management, 46, 187-202. https://doi.org/10.1016/j.tourman.2014.07.005.

Sun, Y. Y. (2014). A framework to account for the tourism carbon footprint at island destinations. Tourism Management, 45, 16-27. https://doi.org/10.1016/j.tourman.2014.03.015.

United Nations General Assembly. (2014). Report of the open working group of the General Assembly on Sustainable Development Goals [A/68/970]. Madrid: UN.

UNWTO Tourism Highlights. (2016). In UNWTO Tourism Highlights, 2016 Edition. https://doi. org/10.18111/9789284418145.

Vizeu, F., Meneghetti, F. K., \& Seifert, R. E. (2012). Por uma crítica ao conceito de desenvolvimento sustentável. Cadernos EBAPE.BR, 10(3), 569-583. http://doi.org/10.1590/S1679-395120120003 00007.

World Travel \& Tourism Council. (2016). Travel and Tourism Economic Impact. In Tourism. http:// www.wttc.org/bin/pdf/original_pdf_file/italy.pdf.

WWAP (World Water Assessment Programme). (2015). The United Nations world water development report 2015: Water for a sustainable world. Paris: UN.

Open Access This chapter is licensed under the terms of the Creative Commons Attribution 4.0 International License (http://creativecommons.org/licenses/by/4.0/), which permits use, sharing, adaptation, distribution and reproduction in any medium or format, as long as you give appropriate credit to the original author(s) and the source, provide a link to the Creative Commons license and indicate if changes were made.

The images or other third party material in this chapter are included in the chapter's Creative Commons license, unless indicated otherwise in a credit line to the material. If material is not included in the chapter's Creative Commons license and your intended use is not permitted by statutory regulation or exceeds the permitted use, you will need to obtain permission directly from the copyright holder.

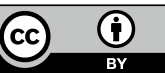

